\title{
Behavioral Risk Factors Of Non-Communicable Diseases Among A Nationally Representative Sample Of School-Going Adolescents In Indonesia
}

This article was published in the following Dove Press journal:

International Journal of General Medicine

\author{
Supa Pengpid (1D) 1,2 \\ Karl Peltzer (D) ${ }^{2}$ \\ 'ASEAN Institute for Health \\ Development, Mahidol University, Salaya, \\ Phutthamonthon, Nakhonpathom, \\ Thailand; ${ }^{2}$ Research and Innovation \\ Office, North West University, \\ Potchefstroom, South Africa
}

Background: The aim of this study was to investigate the prevalence and correlates of behavioral non-communicable diseases (NCD) risk factors among adolescents in Indonesia. Methods: Cross-sectional national data were analyzed from 11,124 in-school adolescents (mean age 14.0 years) of the Indonesia Global School-Based Student Health Survey (GSHS) in 2015. Seven behavioral NCD risk factors (substance use, dietary behavior, overweight or obesity, low physical activity, and sedentary behavior) were assessed by questionnaire in a classroom setting.

Results: The prevalence of low physical activity was $87.8 \%$, insufficient fruit and vegetable intake $76.8 \%$, having soft drinks daily $27.9 \%$, leisure-time sedentary behavior $27.3 \%$, overweight or obesity $15.8 \%$, current tobacco use $12.8 \%$, and alcohol use $4.4 \%$. From the seven behavioral NCD risk factors, the mean was $2.5(\mathrm{SD}=1.0)$, and almost half $(46.5 \%)$ had at least three risk factors. In adjusted linear regression analysis, being a boy, increasing age and psychological distress increased the odds and hunger or food insecurity and parental support decreased the odds for having behavioral risk factors.

Conclusion: A high co-occurrence of behavioral risk factors was identified. Several risk factors (older age, boys, distress, and poor parental support) were identified that can be targeted in intervention programs.

Keywords: dietary behavior, substance use, physical activity, adolescents, Indonesia

\section{Introduction}

Non-communicable diseases (NCDs), such as cardiovascular diseases, cancers, respiratory diseases, and diabetes, cause $71 \%$ of all deaths globally, and over $85 \%$ in low- and middle-income countries. ${ }^{1}$

Behavioral risk factors, such as tobacco use, physical inactivity, the harmful use of alcohol, and unhealthy diets all increase the risk of dying from a NCD. ${ }^{1}$

In Indonesia, NCD-related mortality accounted for $65 \%$ of the deaths in $2010 .^{2}$ In addition, Indonesia has a very high burden of tobacco smoking. ${ }^{2}$ Changes in the environment, lifestyle, and technology in Indonesia have led to an increase of NCDs. ${ }^{3}$ Investigations showed that behavioral risk factors are often acquired during the adolescence period and are then adopted in adulthood. ${ }^{4,5}$ There is a paucity of recent national data on behavioral NCD risk variables in the adolescent population in Indonesia.

In a multi-country study (2003-2011) among adolescents, the prevalence of insufficient fruit and vegetable (FV) intake was $74.3 \%$, low physical activity $71.4 \%$,
Research and Innovation Office, North-

West University, Potchefstroom Campus,

II Hoffman Street, Potchefstroom 253I,

South Africa

Email kfpeltzer@gmail.com 
alcohol use $15.7 \%$, tobacco use $12.1 \%$, and obesity $7.1 \%{ }^{6}$ In the same study, ${ }^{6}$ the prevalence of having at least three NCD risk factors (of five risk factors) was $3.8 \%$ in the Southeast Asia and 6.4\% in Indonesia in $2007 .{ }^{6}$ In adolescents in Indonesia, the proportion of current tobacco use was $20.3 \%$ in $2014,{ }^{7}$ current alcohol use $2.9 \%$ in $2007,{ }^{8}$ insufficient FV intake $75.2 \%$ in $2007,{ }^{9}$ physical inactivity ( $<5$ days) $75.6 \%$ in $2007,{ }^{10}$ leisure-time sedentary behavior ( $\geq 3 \mathrm{hrs} /$ day) was $33.7 \%$ in $2007,{ }^{10}$ and overweight or obesity was $7.0 \%{ }^{11}$ In a study among adolescents in Brazil, 58.5\% reported being exposed to at least two of five behavioral risk factors at the same time, ${ }^{12}$ and among adolescents in Nepal, 11.2\% had 3-5 risk factors. ${ }^{13}$

As reviewed in Pengpid and Peltzer, ${ }^{14}$ factors associated with individual and/or multiple behavioral NCD risk factors among adolescents include male sex, older age, lower socioeconomic status, physical inactivity, insufficient physical activity, not attending physical education classes, overweight/obesity, psychological distress, school truancy, and lack of peer and parental support. The study aimed to investigate the prevalence and correlates of behavioral NCD risk factors in adolescents in Indonesia.

\section{Methods}

\section{Sample And Procedure}

Cross-sectional national data from the 2015 Indonesia GSHS were analyzed. ${ }^{15}$

\begin{abstract}
A two-stage cluster sample design was used to produce data representative of all students in Grades 7-12 in Indonesia. At the first stage, schools were selected with probability proportional to enrolment size. At the second stage, classes were randomly selected and all students in selected classes were eligible to participate. ${ }^{15}$
\end{abstract}

The Ethics Commission for Health Research and Development approved the study and informed consent was obtained from the participating schools, parents, and students. $^{15}$

\section{Measures}

The GSHS measure applied to this analysis was used in this survey (Table 1). ${ }^{16}$ Inadequate FV consumption was classified as less than five or more servings in a day. ${ }^{14,17}$ Overweight and obesity was defined as more than +1 standard deviation (SD) from the median body mass index by age and sex. ${ }^{18}$ Inadequate physical activity was defined as not daily at least 60 mins of moderate to vigorous-intensity physical activity. ${ }^{19}$ Sedentary behavior was defined as spending three or more hours per day sitting. ${ }^{20}$ The psychological distress items (no close friends, loneliness, anxiety, suicidal ideation, and suicide attempt) were summed and grouped into $0=0,1=1$ single, and $2-5=2$ multiple. ${ }^{14}$ The four items on parental or guardian support were summed and classified into three groups, 0-1: low, 2: medium, and 3-4: high support." 14

\section{Data Analysis}

Considering the complex design of the study, data analyses were conducted with STATA software version 15.0 (Stata Corporation, College Station, TX, USA). Descriptive statistics are used to provide frequencies, means, and standard deviations. Multivariable logistic and linear regression analyses were utilized for assessing the associations between independent variables and individual and multiple behavioral risk factors. Cases that were missing were excluded from the analyses. P values $<0.05 \%$ were considered significant.

\section{Results}

\section{Sample Description And Proportion Of Behavioral Risk Factors}

The sample consisted of 11,124 middle-school students (mean age 14.0 years, Standard Deviation 1.6), 51.1\% females and $48.9 \%$ males; $4.1 \%$ had often experienced hunger, $10.9 \%$ had a single psychological distress, and $4.6 \%$ had multiple psychological distress. In terms of protective factors, $79.9 \%$ of the students attended school in the 30 days, $87.6 \%$ had participated in one or more classes of physical education, 39.1\% support of their peers, and $52.0 \%$ had two to four parental support scores.

Regarding individual behavioral risk factors, $87.8 \%$ of the students had low physical activity, $76.8 \%$ had insufficient FV intake, $27.9 \%$ consumed soft drinks daily, 27.3\% engaged in leisure-time sedentary behavior, $15.8 \%$ were overweight or obese, and $12.8 \%$ and $4.4 \%$ were currently using tobacco and alcohol, respectively. The total mean of the measured seven behavioral risk factors was $2.5(\mathrm{SD}=1.0)$, and the distribution of the multiple occurrence of the behavioral risk factors was $0=1.1 \%, 1=11.0 \%, 2=41.4 \%$, $3=32.1 \%, 4=11.1 \%, 5=2.8 \%, 6=0.5$, and $7=0.0 \%$, and $46.5 \%$ had at least three risk factors (Table 2).

\section{Associations With Individual And Multiple Behavioral Risk Factors}

In the adjusted logistic regression model, boys, increasing age, having psychological distress, and participating in 
Table I Variable Description

\begin{tabular}{|c|c|c|}
\hline Variables & Question & Response Options \\
\hline Age & How old are you? & II years old or younger to 16 years old or older \\
\hline Sex & What is your sex? & Male, Female \\
\hline \multirow[t]{2}{*}{ Hunger } & $\begin{array}{l}\text { During the past } 30 \text { days, how often did you go hungry because } \\
\text { there was not enough food in your home? }\end{array}$ & $\mathrm{I}=$ never to $5=$ always $($ coded $\mathrm{I}-3=0$ and $4-5=\mathrm{I}$ ) \\
\hline & Behavioral risk factors & \\
\hline $\begin{array}{l}\text { Current } \\
\text { tobacco use }\end{array}$ & $\begin{array}{l}\text { During the past } 30 \text { days, on how many days did you smoke } \\
\text { cigarettes/use any tobacco products other than cigarettes, such as } \\
\text { sirih, piper betel cerutu, or cigars? }\end{array}$ & $\mathrm{I}=0$ days to $7=$ All 30 days $(\operatorname{coded} \mathrm{I}=0$ and $2-7=\mathrm{I}$ ) \\
\hline $\begin{array}{l}\text { Current } \\
\text { alcohol use }\end{array}$ & $\begin{array}{l}\text { During the past } 30 \text { days, on how many days did you have at least } \\
\text { one drink containing alcohol? }\end{array}$ & $\mathrm{I}=0$ days to $7=$ All 30 days $($ coded $\mathrm{I}=0$ and $2-7=\mathrm{I})$ \\
\hline Fruits & $\begin{array}{l}\text { "During the past } 30 \text { days, how many times per day did you usually } \\
\text { eat fruit such as pineapples, bananas, oranges, or watermelons?" }\end{array}$ & $\begin{array}{l}\text { "I=I did not eat fruit during the past } 30 \text { days to } 7=5 \text { or } \\
\text { more times per day" }\end{array}$ \\
\hline Vegetables & $\begin{array}{l}\text { During the past } 30 \text { days, how many times per day did you usually eat } \\
\text { vegetables, such as carrots, cabbage, spinach, or kangkong/ } \\
\text { kangkung? }\end{array}$ & $\begin{array}{l}\text { I did not eat vegetables during the past } 30 \text { days to } 7=5 \text { or } \\
\text { more times per day }\end{array}$ \\
\hline Height & How tall are you without your shoes on? & $\ldots \mathrm{cm}$ \\
\hline Body weight & How much do you weigh without your shoes on? & $\ldots \mathrm{kg}$ \\
\hline $\begin{array}{l}\text { Soft drink } \\
\text { consumption }\end{array}$ & $\begin{array}{l}\text { During the past } 30 \text { days, how many times per day did you usually } \\
\text { drink carbonated soft drinks, such as Coca-Cola, Sprite, Fanta, or } \\
\text { Big Bola? (Do not include diet soft drinks.) }\end{array}$ & $\begin{array}{l}I=I \text { did not drink carbonated soft drinks during the past } \\
30 \text { days to } 7=5 \text { or more times per day (coded I=once or } \\
\text { more/day) }\end{array}$ \\
\hline $\begin{array}{l}\text { Physical } \\
\text { activity }\end{array}$ & $\begin{array}{l}\text { Physical activity is any activity that increases your heart rate and } \\
\text { makes you get out of breath some of the time. Physical activity can } \\
\text { be done in sports, playing with friends, or walking to school. Some } \\
\text { examples of physical activity are are running, fast walking, biking, } \\
\text { dancing, football, menyapu, mengepel, and menyeterika. During the } \\
\text { past } 7 \text { days, on how many days were you physically active for a total } \\
\text { of at least } 60 \text { minutes per day? }\end{array}$ & $0=0$ days to $7=7$ days $($ coded $0-6=0$ and $7=1)$ \\
\hline \multirow[t]{2}{*}{$\begin{array}{l}\text { Leisure-time } \\
\text { sedentary } \\
\text { behavior }\end{array}$} & $\begin{array}{l}\text { How much time do you spend during a typical or usual day sitting } \\
\text { and watching television, playing computer games, talking with } \\
\text { friends, or doing other sitting activities, such as main play station? }\end{array}$ & $\begin{array}{l}\text { I=Less than I hr per day } \ldots 3=3 \text { to } 4 \text { hrs per day } \ldots 6=8 \\
\text { or more hours a day }\end{array}$ \\
\hline & Psychological distress & Yes, No \\
\hline $\begin{array}{l}\text { No close } \\
\text { friends }\end{array}$ & How many close friends do you have? & $\mathrm{I}=0$ to $4=3$ or more $($ coded $\mathrm{I}+=0,0=\mathrm{I})$ \\
\hline Loneliness & During the past 12 months, how often have you felt lonely? & $\mathrm{I}=$ never to $5=$ always $($ coded $\mathrm{I}-3=0$ and $4-5=\mathrm{I})$ \\
\hline Anxiety & $\begin{array}{l}\text { During the past } 12 \text { months, how often have you been so worried } \\
\text { about something that you could not sleep at night? }\end{array}$ & $\mathrm{I}=$ never to $5=$ always $($ coded $\mathrm{I}-3=0$ and $4-5=\mathrm{I})$ \\
\hline $\begin{array}{l}\text { Suicide } \\
\text { ideation }\end{array}$ & $\begin{array}{l}\text { During the past } 12 \text { months, did you ever seriously consider } \\
\text { attempting suicide? }\end{array}$ & Yes, No \\
\hline $\begin{array}{l}\text { Suicide } \\
\text { attempt }\end{array}$ & $\begin{array}{l}\text { During the past } 12 \text { months, how many times did you actually } \\
\text { attempt suicide? }\end{array}$ & $\mathrm{I}=0$ times to $5=6$ or more times (coded $\mathrm{I}=0$ and $2-5=\mathrm{I}$ ) \\
\hline
\end{tabular}


Table I (Continued).

\begin{tabular}{|l|l|l|}
\hline Variables & Question & Response Options \\
\hline $\begin{array}{l}\text { School } \\
\text { attendance }\end{array}$ & $\begin{array}{l}\text { During the past } 30 \text { days, on how many days did you miss classes or } \\
\text { school without permission? }\end{array}$ & $\mathrm{I}=0$ days to $5=\mathrm{I}$ or more days (coded $\mathrm{I}=\mathrm{I}$ and $2-5=0$ ) \\
\hline $\begin{array}{l}\text { Physical } \\
\text { education }\end{array}$ & $\begin{array}{l}\text { During this school year, on how many days did you go to physical } \\
\text { education }(\mathrm{PE}) \text { class each week? }\end{array}$ & $\begin{array}{l}\mathrm{I}=0 \text { days to } 6=5 \text { or more days (coded } \mathrm{I}-4=0 \text { and } 5-6=\mathrm{I} \\
\text { two or more days) }\end{array}$ \\
\hline $\begin{array}{l}\text { Peer support } \\
\text { Puring the past } 30 \text { days, how often were most of the students in } \\
\text { your school kind and helpful? }\end{array}$ & $\mathrm{I}=$ never to $5=$ =always (coded $\mathrm{I}-3=0$ and $4-5=\mathrm{I}$ ) \\
\hline $\begin{array}{l}\text { Parental } \\
\text { connectedness }\end{array}$ & $\begin{array}{l}\text { During the past } 30 \text { days, how often did your parents or } \\
\text { guardians understand your problems and worries? }\end{array}$ & $\mathrm{I}=$ never to $5=$ always (coded $\mathrm{I}-3=0$ and $4-5=\mathrm{I}$ ) \\
\hline $\begin{array}{l}\text { Parental } \\
\text { bonding }\end{array}$ & $\begin{array}{l}\text { During the past } 30 \text { days, how often did your parents or guardians } \\
\text { really know what you were doing with your free time? }\end{array}$ & $\mathrm{I}=$ never to $5=$ always (coded $\mathrm{I}-3=0$ and $4-5=\mathrm{I}$ ) \\
\hline $\begin{array}{l}\text { Parental } \\
\text { respect for } \\
\text { privacy }\end{array}$ & $\begin{array}{l}\text { During the past } 30 \text { days, how often did your parents or guardians } \\
\text { go through your things without your approval? }\end{array}$ & $\mathrm{I}=$ never to $5=$ always (coded $\mathrm{I}-3=0$ and $4-5=\mathrm{I}$ ) \\
\hline
\end{tabular}

physical education increased the odds and attending school in the past month and higher parental support decreased the odds of both tobacco and alcohol use. Increasing age and school attendance increased the odds and hunger or food insecurity, participating in classes of physical education, and higher parental support decreased the odds for insufficient FV intake. Younger age, attending school, and parental support increased the odds for overweight or obesity (Table 3 ).

Being male, younger age and multiple psychological distress increased the odds and attending school decreased the odds for daily soft drink consumption. Participating in physical education, peer and parental support were protective from low physical activity. Increasing age and psychological distress had an association with sedentary behavior during leisure time. Being a boy, increasing age and psychological distress increased the odds and hungey or food insecurity and parental support decreased the odds for multiple behavioral risk factors (Table 4).

\section{Discussion}

Results found a significant co-occurrence of NCD behavioral risk factors (mean 2.5 and $46.5 \%$ had 3-7 risk factors). This is result is much higher than in a previous older investigation (3.8\% 3-5 risk factors) in Southeast Asia, ${ }^{6}$ Indonesia $(7.0 \%),{ }^{6}$ and Nepal $(11.2 \%) .{ }^{11}$ The prevalence of physical inactivity $(<7$ days) $(87.8 \%)$ in this study was higher than in the older multi-, low-, and middle-income country study $(71.4 \%){ }^{6}$ similar to Indonesia in 2007 (<5 days) $(75.6 \%) .{ }^{10}$ Insufficient $\mathrm{FV}$ intake was about the same $(76.8 \% \text { vs } 74.3 \%)^{6}$ and $75.2 \%$ in Indonesia in $2007,{ }^{9}$ tobacco use (12.8\% vs $\left.12.1 \%\right)$ and lower than in the youth tobacco survey in Indonesia in $2014(20.3 \%)^{7}$ Alcohol consumption was lower than in the large multi-country investigation $(4.4 \% \text { vs } 15.7 \%)^{6}$ and higher than in Indonesia in $2007(2.9 \%) .{ }^{8}$ The proportion of leisure-time sedentary behavior ( $\geq 3 \mathrm{hrs} / \mathrm{day}$ ) was in this study (27.3\%) lower than in the 2007 Indonesia GSHS $(33.7 \%){ }^{10}$ The proportion of overweight or obesity $(15.8 \%)$ in this study was higher than the Indonesia GSHS in $2007(7.0 \%)^{11}$ and in Nepal $(6.7 \%) .{ }^{13}$ In the 2012 Indonesia Demographic and Health Survey, $0.8 \%$ of the never married females (15-19 years) and $13.9 \%$ of the never married males (15-19 years) were current drinkers. ${ }^{21}$ The high occurrence of several risk factors, including low physical activity, insufficient FV intake, and tobacco use, and the increase in the co-occurrence of NCD behavioral risk behaviors, and the increase of overweight or obesity 
Table 2 Sample Characteristics And Distribution Of Behavioral Risk Factors Of Non-Communicable Diseases

\begin{tabular}{|c|c|c|c|c|c|c|c|c|c|}
\hline Variable & Sample & $\begin{array}{l}\text { Current } \\
\text { Tobacco } \\
\text { Use }\end{array}$ & $\begin{array}{l}\text { Current } \\
\text { Alcohol } \\
\text { Use }\end{array}$ & $\begin{array}{l}\text { Inadequate } \\
\text { Fruit And } \\
\text { Vegetable } \\
\text { Consumption }\end{array}$ & $\begin{array}{l}\text { Overweight } \\
\text { Or Obesity }\end{array}$ & $\begin{array}{l}\text { Soft Drink } \\
\text { Consumption }\end{array}$ & $\begin{array}{l}\text { Inadequate } \\
\text { Physical } \\
\text { Activity }\end{array}$ & $\begin{array}{l}\text { Leisure- } \\
\text { Time } \\
\text { Sedentary } \\
\text { Behavior }\end{array}$ & $\begin{array}{l}\text { Total } \\
\text { Behavioral } \\
\text { Risk } \\
\text { Factors }\end{array}$ \\
\hline & N (\%) & $\%$ & $\%$ & $\%$ & $\%$ & $\%$ & $\%$ & $\%$ & $M(S D)$ \\
\hline \multicolumn{10}{|l|}{ Sociodemographic } \\
\hline All & 11,124 & 12.8 & 4.4 & 76.8 & 15.8 & 27.9 & 87.8 & 27.3 & $2.2(0.9)$ \\
\hline \multicolumn{10}{|l|}{ Sex } \\
\hline Female & $6020(51.1)$ & 2.4 & 1.6 & 77.4 & 15.5 & 25.3 & 88.4 & 27.2 & $2.1(0.8)$ \\
\hline Male & 5090 (48.9) & 23.6 & 7.3 & 76.2 & 16.0 & 30.7 & 87.1 & 27.4 & $2.4(1.0)$ \\
\hline \multicolumn{10}{|l|}{ Age } \\
\hline$\leq 13$ & 4549 (43.6) & 9.5 & 3.4 & 71.9 & 18.3 & 31.7 & 88.7 & 20.4 & $2.1(0.9)$ \\
\hline 14 & $2565(24.1)$ & 12.5 & 3.7 & 76.4 & 15.2 & 26.8 & 87.4 & 27.6 & $2.2(0.9)$ \\
\hline 15 & $1943(14.7)$ & 16.3 & 4.5 & 82.7 & 13.6 & 25.6 & 87.4 & 30.3 & $2.4(0.9)$ \\
\hline$\geq 16$ & $2067(17.6)$ & 18.1 & 7.4 & 84.3 & 12.3 & 22.0 & 86.4 & 41.5 & $2.5(0.9)$ \\
\hline \multicolumn{10}{|l|}{ Grade } \\
\hline 7 & $2740(25.9)$ & 10.0 & 4.3 & 71.3 & 17.6 & 32.6 & 91.5 & 15.0 & $2.1(0.8)$ \\
\hline 8 & $2653(25.9)$ & 12.3 & 3.6 & 73.3 & 15.8 & 32.1 & 86.3 & 24.9 & $2.1(0.9)$ \\
\hline 9 & $2656(25.0)$ & 14.6 & 3.7 & 77.8 & 15.2 & 23.3 & 86.3 & 27.6 & $2.3(0.9)$ \\
\hline 10 & 2032 (23.2) & 14.1 & 6.0 & 85.4 & 14.5 & 19.8 & 86.8 & 43.1 & $2.5(0.9)$ \\
\hline Hunger & $482(4.1)$ & 19.9 & 6.0 & 71.6 & 13.5 & 33.5 & 86.4 & 28.1 & $2.2(1.0)$ \\
\hline \multicolumn{10}{|l|}{$\begin{array}{l}\text { Psychological } \\
\text { distress }\end{array}$} \\
\hline 0 & 9117 (84.5) & 10.5 & 2.9 & 76.9 & 15.8 & 27.0 & 87.9 & 25.7 & $2.2(0.9)$ \\
\hline 1 & $1213(10.9)$ & 18.2 & 7.2 & 76.8 & 16.2 & 30.8 & 87.0 & 32.9 & $2.4(1.0)$ \\
\hline $2-5$ & $492(4.6)$ & 23.5 & 13.0 & 78.9 & 14.8 & 32.8 & 85.6 & 39.7 & $2.5(1.1)$ \\
\hline \multicolumn{10}{|l|}{ Protective factors } \\
\hline School attendance & 8660 (79.9) & 9.6 & 3.0 & 77.2 & 16.5 & 26.2 & 87.8 & 26.9 & $2.2(0.9)$ \\
\hline \multicolumn{10}{|l|}{$\begin{array}{l}\text { Attending physical } \\
\text { education classes/ } \\
\text { week }\end{array}$} \\
\hline 0 & 1407 (12.4) & 15.0 & 5.1 & 75.2 & 14.3 & 32.1 & 94.6 & 20.5 & $2.2(0.9)$ \\
\hline 1 & 6847 (63.7) & 10.4 & 3.2 & 78.5 & 15.8 & 26.3 & 87.8 & 27.6 & $2.2(0.9)$ \\
\hline$\geq 2$ & 2706 (23.9) & 17.9 & 6.8 & 73.0 & 16.2 & 30.2 & 84.3 & 29.8 & $2.3(1.0)$ \\
\hline Peer support & $4282(39.1)$ & 10.6 & 3.9 & 75.6 & 16.7 & 25.5 & 85.3 & 29.1 & $2.2(0.9)$ \\
\hline \multicolumn{10}{|l|}{ Parental support } \\
\hline $0-1$ & $5173(48.0)$ & 16.4 & 5.4 & 79.2 & 14.4 & 29.1 & 89.8 & 27.7 & $2.3(0.9)$ \\
\hline 2 & 3174 (29.6) & 10.1 & 3.5 & 76.7 & 15.6 & 26.7 & 87.2 & 28.1 & $2.2(0.9)$ \\
\hline $3-4$ & $2388(22.4)$ & 7.2 & 2.3 & 71.7 & 19.1 & 26.6 & 84.7 & 25.3 & $2.1(0.9)$ \\
\hline
\end{tabular}

and alcohol use are cause of concern needing public health interventions for this population in Indonesia.

Consistent with previous findings, ${ }^{12,13,22,23}$ this investigation found that male sex, older age, and food security or high economic status increased the likelihood of the co-occurrence of behavioral NCD risk factors in this adolescent population. Unlike findings from some previous investigations, ${ }^{23,24}$ the results of this study found no association between not participating in physical education and multiple health-risk behaviors. The findings of this study showed that having psychological distress increased the odds for having multiple behavioral risk factors as well as several individual risk factors, including alcohol and tobacco use, sedentary 
Table 3 Associations With Behavioral NCD Risk Factors (Tobacco, Alcohol, Fruit And Vegetable Consumption, And Overweight Or Obesity)

\begin{tabular}{|c|c|c|c|c|}
\hline \multirow[t]{2}{*}{ Variable } & $\begin{array}{l}\text { Current } \\
\text { Tobacco Use }\end{array}$ & $\begin{array}{l}\text { Current } \\
\text { Alcohol Use }\end{array}$ & $\begin{array}{l}\text { Inadequate Fruit And } \\
\text { Vegetable Consumption }\end{array}$ & $\begin{array}{l}\text { Overweight Or } \\
\text { Obesity }\end{array}$ \\
\hline & AOR $(95 \% \mathrm{Cl})$ & AOR (95\% Cl) & AOR $(95 \% \mathrm{Cl})$ & AOR (95\% Cl) \\
\hline Sociodemographic & & & & \\
\hline $\begin{array}{l}\text { Sex } \\
\text { Female } \\
\text { Male }\end{array}$ & $\begin{array}{l}\text { I (Reference) } \\
\text { I3.36 }(9.09,19.66)^{* * *}\end{array}$ & $\begin{array}{l}\text { I (Reference) } \\
4.32(2.80,6.67)^{* * *}\end{array}$ & $\begin{array}{l}\text { I (Reference) } \\
(0.940 .86,1.02)\end{array}$ & $\begin{array}{l}\text { I (Reference) } \\
\text { I.I }(0.97,1.29)\end{array}$ \\
\hline $\begin{array}{l}\text { Age } \\
\qquad 13 \\
14 \\
15 \\
\geq 16 \\
\text { Hunger }\end{array}$ & $\begin{array}{l}\text { I (Reference) } \\
\text { I.46 }(1.15,1.85)^{* *} \\
2.08(1.53,2.82)^{* * *} \\
2.5 \mathrm{I}(1.64,3.85)^{* * *} \\
\mathrm{I} .17(0.84,1.63)\end{array}$ & $\begin{array}{l}\text { I (Reference) } \\
\text { I.I }(0.82,1.64) \\
\text { I. } 49(0.99,2.23) \\
2.74(1.60,4.67)^{* * *} \\
0.83(0.47,1.44)\end{array}$ & $\begin{array}{l}\text { I (Reference) } \\
\text { I.27 (I.I } 1,1.42)^{* * *} \\
\text { I.83(1.50, 2.23)*** } \\
2.03(1.61,2.55)^{* * *} \\
0.73(0.58,0.91)^{* *}\end{array}$ & $\begin{array}{l}\text { I (Reference) } \\
0.80(0.68,0.94)^{* *} \\
0.72(0.55,0.95)^{*} \\
0.63(0.42,0.95)^{*} \\
0.87(0.62,1.23)\end{array}$ \\
\hline $\begin{array}{l}\text { Psychological distress } \\
0 \\
1 \\
2-5\end{array}$ & $\begin{array}{l}\text { I (Reference) } \\
2.02(1.61,2.54)^{* * *} \\
2.55(1.73,3.77)^{* * *}\end{array}$ & $\begin{array}{l}\text { I (Reference) } \\
2.40(1.67,3.46)^{* * *} \\
4.2 \mathrm{I}(2.77,6.42)^{* * *}\end{array}$ & $\begin{array}{l}\text { I (Reference) } \\
0.97(0.79,1.18) \\
1.14(0.84,1.55)\end{array}$ & $\begin{array}{l}\text { I (Reference) } \\
\text { I.I } 4(0.94,1.38) \\
0.99(0.74,1.32)\end{array}$ \\
\hline $\begin{array}{l}\text { Protective factors } \\
\text { School attendance } \\
\text { Attending physical education classes } / \geq 2 \text { week } \\
\text { Peer support }\end{array}$ & $\begin{array}{l}0.45(0.38,0.54)^{* * *} \\
\mathrm{I} .45(1.15, \mathrm{I} .83)^{* *} \\
0.99(0.8 \mathrm{I}, \mathrm{I} .22)\end{array}$ & $\begin{array}{l}0.44(0.33,0.57)^{* * *} \\
\mathrm{I} .63(1.20,2.22)^{* *} \\
\mathrm{I} .07(0.80,1.43)\end{array}$ & $\begin{array}{l}1.18(1.05,1.32)^{* *} \\
0.79(0.70,0.90)^{* * *} \\
0.92(0.81,1.04)\end{array}$ & $\begin{array}{l}\mathrm{I} .33(\mathrm{I} .07, \mathrm{I} .65)^{* *} \\
\mathrm{I} .03(0.86, \mathrm{I} .23) \\
\mathrm{I} .10(0.96, \mathrm{I} .25)\end{array}$ \\
\hline $\begin{array}{l}\text { Parental support } \\
\quad 0-1 \\
2 \\
3-4\end{array}$ & $\begin{array}{l}\text { I (Reference) } \\
0.72(0.61,0.86)^{* * *} \\
0.52(0.40,0.69)^{* * *}\end{array}$ & $\begin{array}{l}\text { I (Reference) } \\
0.76(0.56,1.04) \\
0.58(0.39,0.84)^{* *}\end{array}$ & $\begin{array}{l}\text { I (Reference) } \\
0.87(0.77,0.99)^{*} \\
0.70(0.61,0.79)^{* * *}\end{array}$ & $\begin{array}{l}\text { I (Reference) } \\
\text { I.07 (0.88, I.29) } \\
\text { I.32 (I.II, I.57)** }\end{array}$ \\
\hline
\end{tabular}

Notes: ***P<0.00I, **P<0.01, *P<0.05.

Abbreviations: $\mathrm{AOR}$, adjusted odds ratio; $\mathrm{Cl}$, confidence interval.

behavior, and consumption of soft drinks daily. It is possible that a "reciprocal relationship exists between mood and the engagement in mood-regulating behaviors (i.e., substance use and sedentary behavior)." 25 This investigation found that school attendance and higher parental support were protective from multiple behavioral NCD risk factors, which is consistent with the findings of previous studies. ${ }^{26-28}$ Interventions to reduce multiple behavioral NCD risk factors may want to reinforce attending school and promoting parental support among adolescents.

Consistent with previous studies, ${ }^{13,23}$ male sex and older age were associated with alcohol and tobacco. In this investigation, participating in physical education was found to be associated with tobacco and alcohol use, while in a previous study, ${ }^{23}$ being inactive while participating in physical education was associated with tobacco use. ${ }^{23}$ In agreement with previous studies, ${ }^{23,24,29}$ this study found that attendance of physical education was protective from low physical activity and inadequate FV intake. Attendance of school was found protective from daily consumption of soft drinks and insufficient FV intake. This finding supports the importance of physical education and other school activities in promoting healthy behaviors. Parental support was protective from several behavioral NCD risk factors, including alcohol and tobacco use, low physical activity, and insufficient FV intake. However, both attendance of school and receiving high support from parents were positively associated with overweight or obesity. Nevertheless, parental support can be utilized in programs preventing substance use and improving dietary behavior and physical activity. 
Table 4 Associations With Behavioral NCD Risk Factors (Physical Inactivity, Leisure-Time Sedentary Behavior, And Total Number Of Behavioral NCD Risk Factors)

\begin{tabular}{|c|c|c|c|c|}
\hline \multirow[t]{2}{*}{ Variable } & $\begin{array}{l}\text { Soft Drink } \\
\text { Consumption }\end{array}$ & $\begin{array}{l}\text { Inadequate } \\
\text { Physical Activity }\end{array}$ & $\begin{array}{l}\text { Leisure-Time } \\
\text { Sedentary Behavior }\end{array}$ & $\begin{array}{l}\text { Total Behavioral } \\
\text { Risk Factors }\end{array}$ \\
\hline & AOR $(95 \% \mathrm{Cl})$ & AOR $(95 \% \mathrm{Cl})$ & AOR $(95 \% \mathrm{Cl})$ & Adjusted Beta $(95 \% \mathrm{Cl})$ \\
\hline Sociodemographics & & & & \\
\hline $\begin{array}{l}\text { Sex } \\
\text { Female } \\
\text { Male }\end{array}$ & $\begin{array}{l}\text { I (Reference) } \\
\text { I.27 (I.I2, I.44)*** }\end{array}$ & $\begin{array}{l}\text { I (Reference) } \\
0.85(0.72,1.01)\end{array}$ & $\begin{array}{l}\text { I (Reference) } \\
0.97(0.85,1.10\end{array}$ & $\begin{array}{l}\text { Reference } \\
0.21(0.15 \text { to } 0.27)^{* * *}\end{array}$ \\
\hline $\begin{array}{l}\text { Age } \\
\qquad \leq 13 \\
14 \\
15 \\
\geq 16 \\
\text { Hunger }\end{array}$ & $\begin{array}{l}\text { I (Reference) } \\
0.78(0.67,0.90) * * * \\
0.74(0.62,0.89)^{* * *} \\
0.61(0.48,0.80)^{* * *} \\
\text { I.25( }(1.00,1.57)\end{array}$ & $\begin{array}{l}\text { I (Reference) } \\
0.89(0.68,1.16) \\
0.94(0.73,1.20) \\
0.80(0.59,1.10) \\
0.87(0.64,1.19)\end{array}$ & $\begin{array}{l}\text { I (Reference) } \\
\text { I.44 (I.23, I.69)*** } \\
\text { I.74 (I.27, 2.38)*** } \\
2.79(1.98,3.93)^{* * *} \\
0.93(0.94,1.17)\end{array}$ & $\begin{array}{l}\text { Reference } \\
0.11 \text { ( } 0.06 \text { to } 0.16)^{* * *} \\
0.25(0.15 \text { to } 0.35)^{* * *} \\
0.38(0.25 \text { to } 0.50)^{* * *} \\
-0.12 \text { (-0.23 to }-0.02)^{*}\end{array}$ \\
\hline $\begin{array}{l}\text { Psychological distress } \\
0 \\
1 \\
2-5\end{array}$ & $\begin{array}{l}\text { I (Reference) } \\
\text { I.I7 (I.00, I.38) } \\
\text { I.30 (I.03, I.65)* }\end{array}$ & $\begin{array}{l}\text { I (Reference) } \\
0.89(0.74,1.08) \\
0.79(0.58,1.07)\end{array}$ & $\begin{array}{l}\text { I (Reference) } \\
\text { I.43 (I.22, I.68)*** } \\
\text { I.82 (I.45, 2.28)*** }\end{array}$ & $\begin{array}{l}\text { Reference } \\
0.17(0.09 \text { to } 0.24)^{* * *} \\
0.26(0.15 \text { to } 0.38)^{* * *}\end{array}$ \\
\hline $\begin{array}{l}\text { Protective factors } \\
\text { School attendance } \\
\text { Attending physical education classes/ } \\
\geq 2 \text { week } \\
\text { Peer support }\end{array}$ & $\begin{array}{l}0.70(0.62,0.79)^{* * *} \\
1.08(0.93,1.27) \\
0.91(0.81,1.02)\end{array}$ & $\begin{array}{l}0.98(0.82, \mathrm{I} .18) \\
0.69(0.53,0.89)^{* *} \\
0.75(0.63,0.89)^{* * *}\end{array}$ & $\begin{array}{l}1.06(0.94,1.19) \\
1.17(1.00,1.36) \\
1.12(1.00,1.26)\end{array}$ & $\begin{array}{l}-0.05(-0.10 \text { to }-0.07)^{* * *} \\
0.001(-0.0 .06 \text { to } 0.07) \\
-0.006(-0.05 \text { to } 0.04)\end{array}$ \\
\hline $\begin{array}{l}\text { Parental support } \\
0-1 \\
2 \\
3-4\end{array}$ & $\begin{array}{l}\text { I (Reference) } \\
0.94(0.83,1.08) \\
0.95(0.83,1.08)\end{array}$ & $\begin{array}{l}\text { I (Reference) } \\
0.79(0.64,0.97)^{*} \\
0.67(0.55,0.81)^{* * *}\end{array}$ & $\begin{array}{l}\text { I (Reference) } \\
1.05(0.93,1.19) \\
0.93(0.81,1.07)\end{array}$ & $\begin{array}{l}\text { Reference } \\
-0.07(-0.12 \text { to }-0.02)^{* *} \\
-0.14(-0.20 \text { to }-0.08)^{* * *}\end{array}$ \\
\hline
\end{tabular}

Notes: $* * * \mathrm{P}<0.001, * * \mathrm{P}<0.01, * \mathrm{P}<0.05$

Abbreviations: $\mathrm{AOR}$, adjusted odds ratio; $\mathrm{Cl}$, confidence interval.

\section{Disclosure}

The authors report no conflicts of interest in this work.

\section{References}

1. World Health Organization (WHO). Non-communicable diseases. 2018. Available from: https://www.who.int/news-room/fact-sheets/ detail/noncommunicable-diseases. Accessed June 5, 2019.

2. Christiani Y, Dugdale P, Tavener M, Byles JE. The dynamic of noncommunicable disease control policy in Indonesia. Aust Health Rev. 2017;41(2):207-213. doi:10.1071/AH15196

3. Purnamasari D. The emergence of non-communicable disease in Indonesia. Acta Med Indones. 2018;50(4):273-274.

4. McPherson KE, Kerr S, Morgan A, et al. The association between family and community social capital and health risk behaviours in young people: an integrative review. BMC Public Health. 2013;13:971. doi:10.1186/ 1471-2458-13-971

5. Selvan MS, Kurpad AV. Primary prevention: why focus on children \& young adolescents? Indian J Med Res. 2004;120(6):511518.
6. Caleyachetty R, Echouffo-Tcheugui JB, Tait CA, Schilsky S, Forrester T, Kengne AP. Prevalence of behavioural risk factors for cardiovascular disease in adolescents in low-income and middle-income countries: an individual participant data meta-analysis. Lancet Diabetes Endocrinol. 2015;3(7):535-544. doi:10.1016/S2213-8587(15)00076-5

7. Rani M, Thamarangsi T, Agarwal N. Youth tobacco use in South-East Asia: implications for tobacco epidemic and options for its control in the region. Indian J Public Health. 2017;61(Suppl 1):S12-S17. doi:10.4103/ijph.IJPH_241_17

8. Balogun O, Koyanagi A, Stickley A, Gilmour S, Shibuya K. Alcohol consumption and psychological distress in adolescents: a multi-country study. J Adolesc Health. 2014;54(2):228-234. doi:10.1016/j.jadohealth. 2013.07.034

9. Peltzer K, Pengpid S. Fruits and vegetables consumption and associated factors among in-school adolescents in five Southeast Asian countries. Int J Environ Res Public Health. 2012;9(10):3575-3587. doi:10.3390/ijerph9103575

10. Peltzer K, Pengpid S. Leisure time physical inactivity and sedentary behaviour and lifestyle correlates among students aged 13-15 in the Association of Southeast Asian Nations (ASEAN) Member States, 2007-2013. Int $J$ Environ Res Public Health. 2016;13(2):217. doi:10.3390/ijerph13020217 
11. Pengpid S, Peltzer K. Overweight, obesity and associated factors among 13-15 years old students in the Association of Southeast Asian Nations Member countries, 2007-2014. Southeast Asian J Trop Med Public Health. 2016;47(2):250-262.

12. Da Silva Brito AL, Hardman CM, de Barros MV. Prevalence and factors associated with the co-occurrence of health risk behaviors in adolescents. Rev Paul Pediatr. 2015;33(4):423-430. doi:10.1016/j. rpped.2015.02.002

13. Dhungana RR, Bista B, Pandey AR, de Courten M. Prevalence, clustering and sociodemographic distributions of non-communicable disease risk factors in Nepalese adolescents: secondary analysis of a nationwide school survey. BMJ Open. 2019;9(5):e028263. doi:10.1136/bmjopen-2018-028263

14. Pengpid S, Peltzer K. Prevalence and correlates of behavioral noncommunicable diseases risk factors among adolescents in the Seychelles: results of a national school survey in 2015. Int $J$ Environ Res Public Health. 2019;16(15):pii: E2651. doi:10.3390/ ijerph16152651

15. World Health Organization (WHO). Global School-based Student Health Survey. Indonesia 2015 Fact Sheet. Available from: https:// www.who.int/ncds/surveillance/gshs/2015_Indonesia_GSHS_ $\overline{\text { Fact }}$ Sheet.pdf. Accessed June 6, 2019.

16. World Health Organization (WHO). Global School-based Student Health Survey (GSHS). 2015 Indonesia GSHS Questionnaire. Available from: https://www.who.int/ncds/surveillance/gshs/2015 GSHS_Indonesia_Questionnaire.pdf. Accessed June 6, 2019.

17. World Health Organization (WHO). Diet, Nutrition and the Prevention of Chronic Diseases. Geneva, Switzerland: WHO; 2003.

18. Cole TJ, Bellizzi MC, Flegal KM, Dietz WH. Establishing a standard definition for child overweight and obesity worldwide: international survey. BMJ. 2000;320:1240-1243. doi:10.1136/bmj.320.7244.1240

19. World Health Organization. Physical activity fact sheet. 2017. Available from: http://www.who.int/mediacentre/factsheets/fs385/en/. Accessed June 6, 2019.

20. Guthold R, Cowan MJ, Autenrieth CS, Kann L, Riley LM. Physical activity and sedentary behavior among schoolchildren: a 34-country comparison. J Pediatr. 2010;157:43-49. doi:10.1016/j.jpeds.2010. 01.019
21. Statistics Indonesia (Badan Pusat Statistik-BPS), National Population and Family Planning Board (BKKBN), Kementerian Kesehatan (Kemenkes-MOH), and ICF International. Indonesia Demographic and Health Survey 2012: Adolescent Reproductive Health. Jakarta, Indonesia: BPS, BKKBN, Kemenkes and ICF International; 2013.

22. Dumith SC, Muniz LC, Tassitano RM, Hallal PC, Menezes AM. Clustering of risk factors for chronic diseases among adolescents from Southern Brazil. Prev Med. 2012;54(6):393-396. doi:10.1016/ j.ypmed.2012.03.014

23. Barbosa Filho VC, de Campos W, Bozza R, Lopes Ada S. The prevalence and correlates of behavioral risk factors for cardiovascular health among Southern Brazil adolescents: a cross-sectional study. MC Pediatr. 2012;12:130. doi:10.1186/1471-2431-12-130

24. Tassitano RM, Barros MV, Tenório MC, Bezerra J, Florindo AA, Reis RS. Enrollment in physical education is associated with healthrelated behavior among high school students. $J$ Sch Health. 2010;80 (3):126-133. doi:10.1111/j.1746-1561.2009.00476.x

25. Arbour-Nicitopoulos KP, Faulkner GE, Irving HM. Multiple healthrisk behaviour and psychological distress in adolescence. J Can Acad Child Adolesc Psychiatry. 2012;21(3):171-178.

26. Allison MA, Attisha E; Council On School Health. The link between school attendance and good health. Pediatrics. 2019;143(2):pii: e20183648. doi:10.1542/peds.2018-3648

27. Pengpid S, Peltzer K. Parental involvement and health risk behaviours among school-going adolescents in six African countries. $J$ Psychol Afr. 2018;28(3):212-217. doi:10.1080/14330237.2017.1409 481

28. Pengpid S, Peltzer K. Parental involvement, health behaviours and mental health among school-going adolescents in six Asian countries. ASR Chiang Mai Univ J Soc Sci Hum. 2016;3(2):115-132. doi:10.12982/CMUJASR.2016.0007

29. Silva DAS, Chaput JP, Tremblay MS. Participation frequency in physical education classes and physical activity and sitting time in Brazilian adolescents. PLoS One. 2019;14(3):e0213785. eCollection 2019. doi:10.1371/journal.pone.0213785
International Journal of General Medicine

\section{Publish your work in this journal}

The International Journal of General Medicine is an international, peer-reviewed open-access journal that focuses on general and internal medicine, pathogenesis, epidemiology, diagnosis, monitoring and treatment protocols. The journal is characterized by the rapid reporting of reviews, original research and clinical studies across all disease areas. The manuscript management system is completely online and includes a very quick and fair peer-review system, which is all easy to use. Visit http://www.dovepress.com/ testimonials.php to read real quotes from published authors. 